His fame and reputation, however, have been dogged by controversy and paradox. The same Haber-Bosch process could be used to make high explosives, enabling Germany to prolong the trench warfare of the First World War despite a Royal Naval blockade of mineral nitrogen.

Haber's reputation has been further besmirched by his involvement in poison-gas warfare. On the afternoon of 22 April 1915, Haber and a troop of gas scientists opened the valves of nearly 6,000 cylinders containing chlorine gas in liquid form. A blanket of thick green-yellow gas swept into the Allied trenches, killing some 5,000 Allied troops (a figure that would be revised downwards by Germany after the war) and injuring 10,000 more. The Germans gained only one mile on the Ypres front as a result. Haber was disappointed: he hadhoped to unleash a weapon of mass destruction so powerful that it would bring the war to an abrupt end, and he blamed his generals for restricting its use.

These actions earned Haber the reputation of a war criminal, forcing him into hiding for a period after the war. But there was worse. It was Haber who oversaw the research that created the insecticide Zyklon B, which, a decade after this death, would be used in the Nazi gas chambers on his own relatives.

There has long been a need for a book in English on the life of Fritz Haber, and Daniel Charles is the ideal biographer. His previous book, Lords of the Harvest, explored biotechnology and the global food supply, an essential dimension of the Haber story.

In Between Genius and Genocide, Charles takes in the huge range of Haber's scientific, technological and patriotic interests, including his quest for cheap gold to beat the postwar reparations burden. A typical Haber scheme, hare-brained from one perspective and yet eminently practicable from another, was his attempt in the 1920 s to harvest gold from the sea. The Swedish chemist Svante Arrhenius had found tiny amounts of gold in sea water and calculated that every ton of the ocean contained 6 milligrams of the precious metal. After extensive experiments and many trips on the oceans of the world, Haber discovered that Arrhenius was wildly out: sea water contains only 0.01 milligrams of gold per ton.

Nor does Charles neglect the turmoil of Haber's private life, including his marriages. The tale of the suicide of Haber's first wife, Clara - an event that has prompted various contradictory accounts - is a model of scrupulous biography. Clara, one of the first women to get a $\mathrm{PhD}$ in Germany, had married Haber in the hope of sharing in his life in science. But it seems she was increasingly isolated by his preoccupation with work, and during the First World War deplored his use of poison gas. After returning from Ypres, Haber threw a party and Clara found him in an "embarrassing situation" with the woman who was to become his second wife. After he

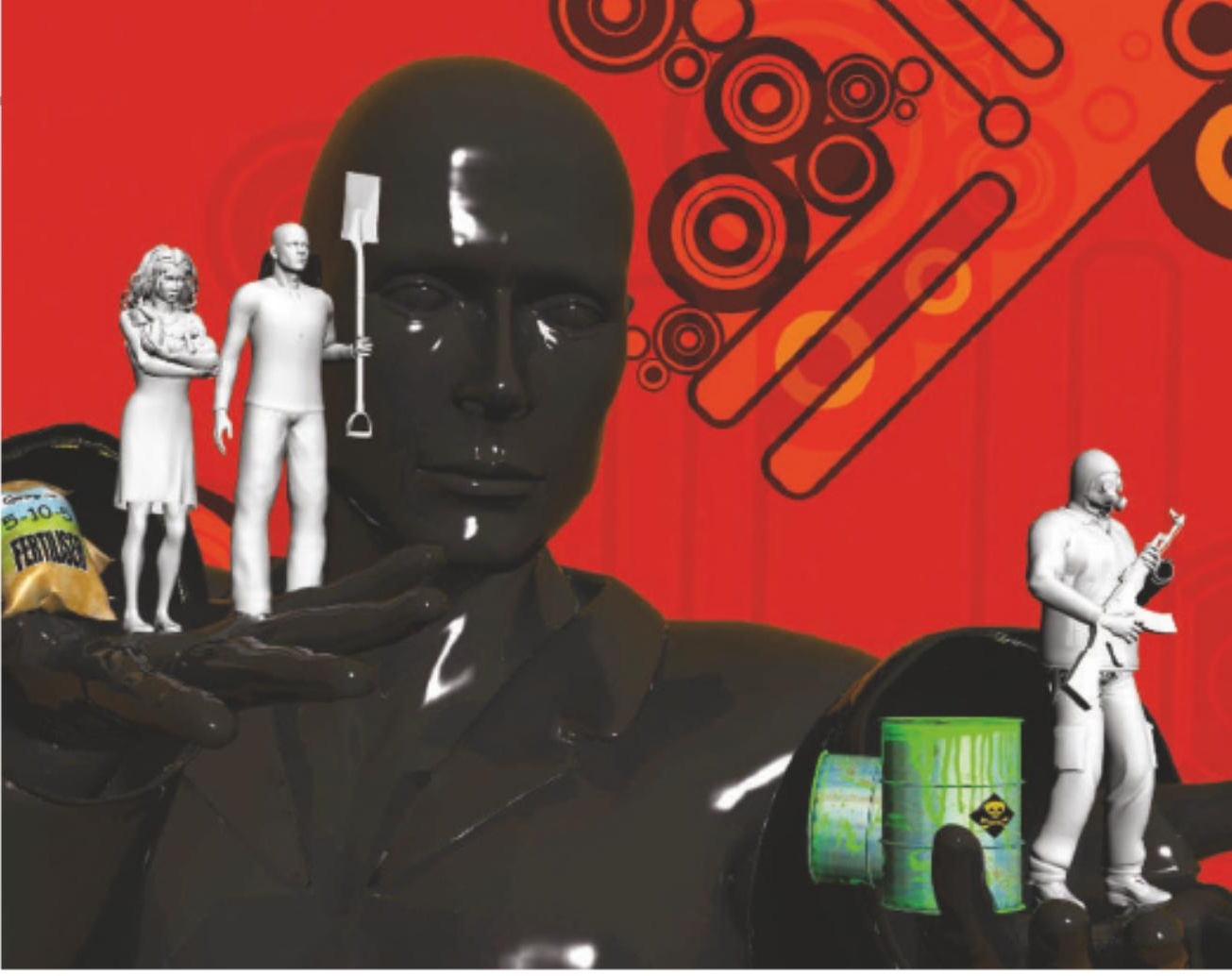

had fallen asleep, she took his service revolver and killed herself.

But Charles's principal focus is Haber as a faustian embodiment of science and technology in the twentieth century. For Charles, Haber's fatal flaw is his willingness "to serve any master who could further his passion for knowledge and progress. He was not an evil man." Charles draws the chilling conclusion that the moral choices that Haber confronted during his life "were not so different from those that we face today".

Charles might have gone further to reflect that underlying Haber's flaws is the proposition, widely accepted and promoted by those involved in the public understanding of science today, that science is morally neutral. The Janus-faced nature of the Haber-Bosch recipe seems to support the contention. In Germany, moreover, scientists traditionally worked under the auspices of a civil service that was both apolitical and value free. Yet it was precisely this neutrality that provided an alibi for the German scientific community when Jewish researchers were expelled after the Nazis came to power. Haber was forced out of the Kaiser Willhelm Institute, which he helped to found in Berlin, despite Max Planck's attempt to argue his case with Hitler. "A Jew is a Jew," Hitler shouted.

The Institute for Physical Chemistry in Berlin now bears Haber's name, but this is still controversial. As the historian Fritz Stern comments in his elegant essay on Haber and Einstein: "The memory lives on — dimly in distorted controversy. Charles's admirable biography will elucidate the controversy and shed fresh light on Haber's memory. John Cornwell is director of the Science and Human Dimension Project, Jesus College, Cambridge, UK, and is the author of Hitler's Scientists.

\title{
Short cut to space-time
}

\section{A Briefer History of Time}

by Stephen Hawking with Leonard

Mlodinow

Bantam Books: 2005. 176 pp. $\$ 25$

\section{Jim Al-Khalili}

The phenomenal success of Stephen Hawking's A Brief History of Time demands that the arrival of this new edition be treated as a major publishing event. So let me begin with a few facts. First, A Briefer History of Time is not a new book, but rather an updated and reworked edition of the original. Second, it is certainly briefer, at three-quarters the length of the original. Third, the simple black-andwhite diagrams of the first book have been replaced by stylish colour images, ranging from the amusing (Hawking and co-author Leonard Mlodinow strapped into their time machine) to the misleading (space-times, of expanding universes and wormholes, embedded within space-time).

So what is the motivation for A Briefer History of Time? I will leave aside any cynical accusation of opportunistic marketing because I believe the authors have made an honest attempt here to rectify what they perceive as a problem with the original: that millions of readers with no scientific background did not get beyond the first chapter before their brains blew up. To remedy this, that first chapter has been chopped into three bite-sized 
